$51 \mid 2020$

Ladakh Through the Ages. A Volume on Art History and Archaeology, followed by Varia

\title{
The fragrance of belonging in Russian Beringia
}

La fragrance de l'appartenance en Béringie russe

Jaroslava Panáková

\section{(2) OpenEdition}

1 Journals

Electronic version

URL: https://journals.openedition.org/emscat/4557

DOI: $10.4000 /$ emscat.4557

ISSN: 2101-0013

Publisher

Centre d'Etudes Mongoles \& Sibériennes / École Pratique des Hautes Études

Electronic reference

Jaroslava Panáková, "The fragrance of belonging in Russian Beringia", Études mongoles et sibériennes, centrasiatiques et tibétaines [Online], 51 | 2020, Online since 09 December 2020, connection on 13 July 2021. URL: http://journals.openedition.org/emscat/4557 ; DOI: https://doi.org/10.4000/emscat.4557

This text was automatically generated on 13 July 2021.

(c) Tous droits réservés 


\title{
The fragrance of belonging in Russian Beringia
}

\author{
La fragrance de l'appartenance en Béringie russe
}

Jaroslava Panáková

\section{Introduction}

1 As the senses mediate human experience, their centrality to the anthropological endeavour seems inevitable. Until World War I, when anthropology formalised itself as a discipline, it sought to explore the complete sensorium. David Howes (2003, p. 5) concludes that, for instance, the goal of Alfred Cort Haddon's 1898 Expedition to the Torres Straits Islands was to prove the hypothesis (advocated in philosophy, Le Guérer 2002, p. 3) that in European civilised cultures the "higher" senses such as sight and hearing dominate, while taste, touch, and smell, the "lower" senses, associated with animality, prevail in the primitive cultures, such as among the Torres Islanders (see Myers \& McDougall 1903). As Sarah Pink suggests: “[...] the colonial project entailed an initial application of anthropological methods to an interdisciplinary project with nonacademic ends, and the sensorium was implicated in the early anthropological theory that informed colonialism" (Pink 2006, p. 5). Nevertheless, the following development of the discipline, especially, the advocacy of cultural translation, a comparison of cultures as integrated wholes, and relativism, favoured linguistic rather than sensory approach. Such loss of interest in the senses was further conditioned by the mistrust in technology by the discipline's dominant figures (Pink 2006, pp.6-7), such as of Bronislaw Malinowski who argued for the cultivation of human sensibility that repudiates mechanical skills (Grimshaw 2001, p. 54) and Franz Boas, who suggested that culture could only be understood historically (Jacknis 1984).

2 Although in the next periods of anthropological research, exploration of the visual (mostly through ethnographic film) still procured a certain position in the field, all other senses remained understudied. The 1980's crisis of representation together with the growing interest in phenomenology (Csordas 1994) and emotions (Stoller 1989), 
brought the senses to the fore; it was understood that adoption of intuitive and emotional knowledge stems directly from our multiple sensory and emotional encounters in the field (Beatty 2005). Since this so called "sensual turn" (Classen 1993; Howes 2003), we have witnessed a growing body of literature in sensory anthropology ${ }^{1}$.

This study aims to contribute namely to the olfactory research. While anthropology had been hesitant to conduct systematic research of olfaction until ca.1990s, other scientific disciplines have built a very consistent stock of knowledge on olfaction ${ }^{2}$. This research serves as a priceless source of inspiration for today's sensory and/or olfactory anthropology.

In classical anthropology, researchers a) explored odours mostly through or alongside other thematic domains, such as religion and rituals (see Leenhard 1979; Lambek 1981), linguistic anthropology and semiology (see Sperber 1975, chap.5), b) described olfaction as an element of a studied culture, distinct from others (see Myers \& McDougall 1903 or Bogoras 1904), or c) recognised odours as a vital aspect of field experience and a condition for understanding the world (Lévi-Strauss 1955, p. 85). Although these studies are absolutely propelling for today's olfactory research, there are certain limits to them.

One of the downsides relates to the ways the olfactory sensation was generally viewed: odours seemed to be too subjective to provide any precise information about external objects, and thus bring any true knowledge (Le Guérer 2002, p. 4). Now it is clear that three steps had to be undertaken in order to acknowledge olfaction as a vital subject for the research (Candau \& Jeanjean 2006, p. 52). Firstly, only when an anthropological self was recognised, could anthropology accept the importance of olfactory sensations in social dynamics. Secondly, notwithstanding subjectivity of the olfactory experience for every individual, olfactory sensation (together with its representation, evaluation, memorisation; Candau 2001), categorisation (Rouby \& Sicard 1997), and integration into spatial cognition (Rodaway 1994), is not shut within an individual conscience, but is culturally determined (Corbin 1982) and shared within (a) group(s) (Candau \& Jeanjean 2006 , p. 53). The third step was to reconcile the scientific legitimacy of the anthropology of odours with the reality of the phenomenology of intermodal perception (Candau 2016, p. 45).

6 Today, the olfactory anthropological inquiry focuses on the cultural modalities of individual sensations within the limits set by (anatomic, physiological) human nature (Candau \& Jeanjean 2006, p. 53). Although humans share the same anatomic and physiological features (regardless some idiosyncrasies and pathologies), there is not only high variability in the individual capacity for general olfactory acuity, given by individual human characteristics such as age, sex, body weight, etc. (Hudson \& Distel 2002), but also immense cultural, inter-group variations in odour perception and representations ${ }^{3}$. Anthropology aims to provide a "mapping [of] cross-cultural variations in the tone and shape of consciousness in accordance with variations in cultural constructions of the sensorium" (Howes 2002, p. 79).

Thematically, anthropology of olfaction (Candau 2016) of the last three decades has evolved around the following domains: a) cultural history of odours ${ }^{4}$; b) cultural variability of the olfactory perception ${ }^{5}$; c) everyday olfactory practices ${ }^{6}$; d) symbolic practices of identification, social categorisation and group hierarchisation ${ }^{7}$; e) change and transition ${ }^{8}$; f) olfactory expertise ${ }^{9}$ and competence in the production and exploitation of aromatic substances ${ }^{10} ;$ g) olfactory human ecology and geography 
(smellscapes $)^{11} ;$ h) cultural context of odour encoding, olfactory lexicons, and linguistic categorisation ${ }^{12}$; i) arts and communication ${ }^{13}$. This study puts a link between symbolic practices of identification and the process of transition.

\section{Conceptualisation}

8 In my study, I aim to explore how the smells associated with particular emotions encode the sense of belonging. I will look at the ways, in which olfactory practices inform a sense of local identity, and the ways people negotiate their identities alongside the changing sentiments evoked through smells in the context of transforming social settings. I will attempt to contextualise the differing olfactory patterns within broad socio-political processes unfolding in the coastal hamlets of Russian Beringia during the Soviet and post-Soviet modernisation.

This context deserves a brief introduction: modernisation project in Soviet Russia promised a great leap, not simply into modernity, but a superior form of modernity (Kotkin 1995). Siberia and the Far North have always had a special position in this process. The notion of the appropriation of the vast and remote periphery, the Siberian land (Rus. osvoenie Sibiri), taken from the previous regime, went along with the mission civilisatrice of its population, "natives" (Rus.tuzemtsi) or "indigenous population" (Rus. korennoe naselenie), whose status contrasted to the category of "full-fledged" citizens, "civilised" representatives of mother countries. At the same time, the evidence from Siberia (e.g. Ural-Siberian Method implemented since 1928) suggests that 'policies were not always vertically channelled 'from above' in the pure totalitarian fashion, but often emerged from a complex bureaucratic interaction between the centre, regional and local tiers of government" (Hughes 1996, p. 207). The ambiguity in the interrelatedness of the totalitarian, collectivist state with the individual biography, where individual experience is shaped by the state institutions and should cohere with - and exemplify the state policy but not always does, can be traced in daily sensory experience.

Therefore, I turn to olfactory experience to explore the potential ambiguity in the interaction between individuals and the state institutions. I suggest that odours act as the codes that is a system of signals, often to communicate an attitude or meaning without stating it explicitly. My focus is to explore how the process of re-identifying oneself together with reconstituting the meaning of "where is my place", "what is my home", "what is my culture" or "where I belong" (personally, socially, culturally, ethnically, etc.), is inevitably coded through the odours of various cultural artefacts and material practices, such as the body, clothes, subsistence, living and working spaces, and the ecological environment, etc.

11 Since most physiological and cognitive processes ${ }^{14}$ are difficult to access by usual anthropological methods, anthropologists draw attention to the ways people represent, describe, and categorise two olfactory categories: either 1) the olfactory stimuli, i.e. the sources of odorous sensation (e.g. "fragrant molecules of a rose") (Barkat-Defradas \& Motte-Florac 2016), or 2) the odours as intersubjective mental representations of the aromatic stimuli made possible by the sense of olfaction. In the latter case, the mental representations stem up from the a) allo-centred reference or b) auto-centred reference. In other words, the perceived odours can be described either by their 
sources - "smell of a rose"15 - or through their effect on one's body and well-being - "it mesmerises me like the smell of a rose"16 (Rouby \& Bensafi 2002, p. 148).

In this study, I will treat odours as the mental representations of the odorous stimuli (b). In this way, they do not express just a particular quality, but point to the category that is socially constructed. The effects made by the stimuli imply a culturally learnt emotion attached to them. Although the source (aromatic molecules of a rose) is a mixture of flowery and faecal odours, as Egon Peter Köster claims, most European cultures find the smell pleasant and associate it with love and tenderness (Köster 2002, p. 30). Following David Howes, I assume that the cognitive dimensions of olfaction are in concert with the cultural politics of olfaction (Howes 2002, p. 79).

13 As the sensorium is culturally constructed, "each culture must be approached on its own sensory terms if its perceptual world is to be apprehended and described accurately by the anthropologist" (Howes 2002, p. 74). Engagement with the ways my informants describe the stimuli is justified by the premise that, if they as members of a certain community represent a particular odorant in the same way, they share a similar olfactory experience. These sensory experiences turn into metaphors taken to represent cultural ideals (Classen 1993). Thus, my role is to explore the nature of these experiences, the measures to which they are shared within the community, the ways they are inscribed in other cultural, social, political, economic, and aesthetic models, and the effects such experience have on the lives of people.

It is especially important to track down transitory moments, such as changes in cultural or social regimes. I assume that a process of Sovietisation and postSovietisation has intensified the dynamics of contestation over olfactory categories, particularly if a group finds itself stigmatised by virtue of their representation in the sensory and social order (Classen et al. 1994). Drawing on Rodney Needham's term category-change, Howes maintains that the connection between the smell and the process of change is universal (Howes 1987, p. 398). I argue that it is at the moments of materialisation and dematerialisation when other senses are in suspense that the sense of smell comes into play the most (Gell 1977); this is valid both for micro transitory occasions, such as herbal incense burnt to define the boundary between sacred and profane spaces, and for broad social transformations (such as transition to postsocialism) that include critical changes in sensory models, for instance, a group rejection of certain smells for the sake of a new collective identity. Changing cultural models make the (olfactory) senses conform and transform, giving rise to a new model of cultural aesthetic and material practices, driven by new sensory values (YaminPasternak et al. 2014, p. 634).

15 Sovietisation can be viewed through the policies and ideologies imposed on peoples in order to exert pervasive cultural hegemony over aesthetic forms (Yurchak 2006). This is even more relevant in the native context ${ }^{17}$. David Chaney's concept of lifestyle (drawing on Pierre Bourdieu's concept of "distinction", 1984) can be helpful in the investigation of the interrelation between social differentiation and aesthetic patterns (Chaney 1996).

16 Numerous authors describe the impact of the Soviet mission civilisatrice on native olfactory practices as a "quest for civility" (Rus. kul'turnost'). These authors focus on various forms of odour sensations based on food preparation and consumption, e.g. the recent transformation of attitudes toward fragrant indigenous cuisines (YaminPasternak et al. 2014) or reshaping people's taste through education at Soviet boarding 
schools (Kozlov et al. 2007). Similar foodways are described by other Arctic anthropologists outside Russia (Jolles \& Oozeva 2002; Searles 2002, 2016; Spray 2002; Spray Starks 2007, 2011). I will look at the cases of olfactory practices beyond the food pathways in order to demonstrate that the realms where the senses, aesthetic, and social hierarchies overlap have a wide spectrum of cultural forms, often unintended from the point of view of the Soviet or post-Soviet policy makers.

Furthermore, in making the smells and emotions central to understanding wider social issues, such as configurations of aesthetics, cultural production, and social differentiation, this study challenges the concept of "lifestyles" itself (Chaney 1996, p. 101): I shift the focus from the management of visual cues to odours. I also maintain that the concept of "deodorisation" (Jenner 2000, 2011) needs to be reconsidered. The concept of deodorisation draws on the cultural history of the Western world, in which sanitation has been attached to the belief in civility and civilisation. As a result, "lowering of odorous tolerance" (Corbin in Jenner 2011, p. 338) or "olfactory blandness" (Classen et al. 1994, pp. 68, 77-78) occurred. This led to "a vast deodorisation project" (Corbin in Jenner 2011, p. 338) or "olfactory revolution" (Classen et al. 1994, pp. 77-78), when modern society had become deodorised. The colonising tone is added when this deodorisation project divides the societies into modern and pre-modern; it accentuates the stereotype that "simpler societies" lived amid stench and squalor, whereas historically, the negative odours prevailed "in historical settings marked by poverty and a rapid shift to urban living-moments and cultures better understood as experiencing or entering modernity" (Jenner 2011, p. 339). In the Russian context, the concept of deodorisation falsely structures the $20^{\text {th }}$ century modernization of the North into three eras: the odorous pre-Soviet past, the following repudiation of strong odours through the Soviet policies, and a return towards some native fragrances as identifiers of distinction in the post-Soviet era. Such narrative is oversimplified; no doubt, it needs further testing. The proposed focus will help us pose the questions in the proliferating literature on Soviet modernisation anew.

\section{Field site}

This study is based on qualitative methodology (in-depth interviews and participant observations) conducted during long-term fieldwork in Chukotka, Russia in the summer 2010, spring 2011 and summer 2014. I collected ethnographic data in several coastal hamlets, New Chaplino, Yanrakynnot, and Sireniki (rural population of the whole district counts to 1953; in each hamlet the population is appr. 400 inhabitants), the semi-urban centre of the Providensky district, Providenya (1 970 inhabitants), and the capital city of Chukotsky Autonomous Region, Anadyr (pop. 13 045). The district (Rus. okrug) is populated by several indigenous groups, the most numerous among them are Chukchi 12772 (approx. 25,28\% of the population of the district) and Siberian Yupik people 1529 (3,03\% of the population of the district) (All-Russian Population Census 2010); non-natives include Russians, Ukrainians, and Moldavians.

19 The local indigenous population has undergone radical transition throughout the $20^{\text {th }}$ century. Since the establishment of the Soviet administration on the Chukchi Peninsula in 1922 (Krupnik \& Chlenov 2013, p. 15), the social models characteristic for the contact-traditional era have diminished. For instance, the traditional Yupik settlement model-central tribal village with its associated small clan-based 
settlements and seasonal camps (Krupnik \& Chlenov 2013, p. 125) was first used by the Soviet regime to establish a short-term self-government through selected new Yupik leaders obedient to the new administration. Ungaziq (Chaplino), largest Siberian Yupik community of Russia's Chukchi Peninsula, became a hub of the "Eskimo native district" (Krupnik \& Chlenov 2013, p. 229). During the collective farm era (1933-1955), as a result of the Soviet "policy of enlargement" (Rus. politika ukrupnenia), people from the small hamlets (e.g. Avan, Siqlluk, Qiwaaq and Tasiq) now viewed as weaker collective farms had to abandon their home place and move to the largest collective farm, Ungaziq. New model was "one collective farm - one village council - one community" (Krupnik \& Chlenov 2013, p. 248). During the reform in 1955-1960, the campaign culminated in the relocation of Ungaziq to a newly built village, closer to the administration centre, Provideniya. The natives of Ungaziq, used to the skin- and sod-covered family cabins (occasionally interspersed with prefabricated frame houses containing the village council office, elementary school, and store) (Krupnik \& Chlenov 2013, p. 246) and summer dome-shaped tent made by fastening skins and furs over a framework of poles (Rus. yaranga) in the seasonal camps now had to move to New Chaplino, constructed as a grid of lined streets of duplex family residences (Krupnik \& Chlenov 2013, p. 279). In the late Soviet period, a few concrete-panelled apartment buildings were added. Another overhaul occurred at the beginning of 2000s: a new school building, village council office, and store were built, the duplex houses were replaced by the prefabricated modular family cottages.

The state top-down policies, such as controlled housing, had impact on the social and kinship ties. The lineage remained but the clan system changed from "self-sustainable unit" to "symbolic social element" (Krupnik \& Chlenov 2013, p. 290). Yupik adaptation strategy, namely a shift from kin to residential social networks (Krupnik \& Chlenov 2013, p. 149), to confront disruptive impact of the rapid change worked in the early contacts with Russians (1700s) and later with American whalers and traders (Krupnik \& Chlenov 2013, p. 148), but not as much so during the Soviet modernization. "The ability of individual loci to migrate and to make new aggregations with other loci by creating new communities and tribes" (Krupnik \& Chlenov 2013, p. 290) became obsolete in the new social regime. The collective farm system and relocation had obvious effects on the subsistence economy: Tkachen Bay was ill-suited for hunting, which lead to the longdistance hunting and hunting at the seasonal camp. Men busy with the construction of the new village ceased to hunt (1959-1964) and the number of hunting crews declined (Krupnik 2000, pp. 210-220). The marine hunting was provided by the cruiser Zvezdnyj; main sea mammal production was industrialised. Since 1970, the hunting in crews was sporadic (there were 1 or 2 crews only) (Krupnik 2000, p. 153). It was not until late 1990s, when the whaleboat hunting in the crews was reinvented again.

Similar transitions occurred in the Chukchi community. In addition, the reindeerherding groups were confronted with sedentarisation and had to move from tundra to the village, often far from the place of their origin. In the second half of the $20^{\text {th }}$ century, the number of Chukchi increased also in New Chaplino. As the village was established by the Soviet administration and its location fell within the traditional reindeer-herding pathways, the village had never been uniquely Yupik. The local Chukchi get involved in the regular life of the village: marine hunting, small-scale inland hunting, sea and lake fishing, and bird hunting. Otherwise, they are either employed in the non-customary state-owned economy (local school, administration, Housing Management - electricity, heating, cleaning) or officially unemployed. Unlike 
contact-traditional era (1900-1923), when Chukchi-Yupik marriages were rare, Soviet modernization had an impact on the overall increase of interethnic conjunctions (including other ethnicities, too). While the patrilineality cannot be considered as a general rule for filiation among Yupik anymore ${ }^{18}$, other factors come into play when choosing ethnic identity. The lingua franca is Russian; formal education also occurs in the Russian language.

Drawing on all these reasons, I suggest that the given community will be explored as one complex; I will not overlook tribal, ethnic, and cultural origin, but at the same time I must take seriously the multi-layered ties, affiliations, and exchanges between the ethnic groups. In literature, authors usually focus on either the Chukchi or Yupik people. If exchange is mentioned, it is the age-old cooperation of coastal hunters with reindeer herders of the tundra that is singled out (Krupnik \& Chlenov 2013, p. 145). Apparently, Soviet modernization and post-Soviet era have transformed the relationships between the groups with the Bering coastal area.

Important account of the relationship between incomers and natives in 1990s and early 2000s is given by Patty Gray (2005). She describes the division along ethnic and territorial lines inscribed in local people's perception, natives' and incomers' alike. In Anadyr, considered modern and progressive hub, natives' "indigeneity" is subdued, all are incomers united by an expected standard of "pan-urban civility" (Yamin-Pasternak et al. 2014, p. 626). In contrast, villages are seen as "native" or "ethnic". This does not prioritise indigenous ethnic groups in their "homes", on the contrary, such division creates alibi for their inferior social status as "natives" can be easily equated with "backward". As Svetlana Yamin-Pasternak et al. put it: "any instance of newcomer ${ }^{19}$ presence was sufficient to turn the nominally categorized 'Native settlement' into a Russian domain" (Yamin-Pasternak et al. 2014, p. 626). The local people conceive and reflect upon the diverse tonalities of the status differentiation based on ethnicity and inhabited space. As a result, the mosaic of affiliations, identifications and modes of interactions is truly manifold. I will build on this entanglement of the local groups and, despite the distinctions, which I will pinpoint throughout the study, I will also stress numerous occasions that emerge from this co-existence and that are absolutely crucial.

\section{The smells}

Chaney conceptualises his notion of "lifestyles" mostly in the context of Western modern societies, which he defines predominantly by their cultures of consumption. Lifestyles are creative and aesthetic projects, "forms of enactment in which actors make judgements in delineating an environment" (Chaney 1996, p. 92). In the new social order of Modernity, Chaney suggests that identities, affiliations and hierarchies are structured through new sensibilities. Chaney defines a "sensibility" as "[...] a way of responding to events, or actions or phenomena that has a certain pattern or coherence, to the extent that identifying a sensibility provides a way of explaining or predicting responses to new situations" (Chaney 2006, p. 8). One such new sensibility is the distinction between public and private spaces; a brutal public sphere contrasts with the gentility of a private space structured through the ideology of domesticity that implies distinctive social groupings, patterns of actions, and a set of expectations (Chaney 1996, p.11). He adds: "Lifestyles were a product of the privatisation of communal life" (Chaney 1996, p. 95). According to Chaney, the patterns of action that differentiate 
people and spaces rely heavily on visualisation, appearance, and design in the material culture. People conduct "active aesthetics" (Chaney 1996, p. 147): they manage visual cues or "surfaces" (Chaney 1996, chap. 7), while being reflexively aware of objects to use and the associations these objects evoke. In this process of fashioning and selffashioning, they seek to sustain their social membership defined by the materiality of cultural forms (Appadurai 1986, Miller 1991).

Among the dozen examples coming from different Siberian localities, the research project "Conditions and Limitations of Lifestyle Plurality in Siberia" (Habeck 2019) shows that Chaney's concept, of course with modifications, is valid also beyond Western societies. On this occasion, I will be able to demonstrate that the expressive behaviours that signal, structure, and negotiate the hierarchisation of the social terrain do not limit themselves to observable, visually articulated cues. My focal concern is the management of olfactory cues. I argue that people actively reflect on the olfactory meanings associated with certain material objects, e.g. food, home interior, skin, etc., and on the values and emotions these smells evoke, and can, thus, intentionally incorporate those material objects into different performative demarcations of sensibility. People use the smells in the social terrain as (provisional) emotional and ethical constructs; this is possible as the smells have the capacity to sustain their identities and, at the same time, allow negotiation over the current status differences. The account of several examples from the terrain will show the smells that are linked with the emotion of belonging, how these odours mark private and public spaces, and how these olfactory affiliations signal social distinctions. In particular, I suggest a number of ways in which olfaction, i.e. its confirmation (rather than repudiation as in deodorisation) is significant in the social regimes of the last five decades in Chukotka. An emphasis on the smells addresses the importance of transitions - the context in which objects or places or people present themselves or are presented through the odours the most vividly.

\section{The cases}

\section{The body/ies}

Bogoras' account of olfaction among the Chukchi people is quite detailed (Bogoras 1904, pp. 38-40). His claim that their "smell seems to be more developed than with civilised races" is not based as much on the Western concept of deodorisation but rather on the olfactory sensitiveness of the particular group, that is, of course, culturally determined; he writes that the locals "assert that every man has a smell peculiar to himself, and that his clothes, etc., can be ascertained from it". Especially in the interethnic contacts, e.g. with Koryaks, he insists, the Chukchi could distinguish their group from others according to the smell of the remains in the camp (Bogoras 1904, p. 38).

On the basis of my observation, this practice of olfactory group differentiation survived the Russian colonisation of the region beginning in the $18^{\text {th }}$ century, contacts with other foreign powers in the $19^{\text {th }}$ and early $20^{\text {th }}$ century (the American, British, Norwegian), and the Soviet-era social engineering. The group distinction through odours resisted even the Soviet assault on the local smells, such as the introduction of water into the everyday life of the natives in the Soviet times (Yamin-Pasternak et al. 2014, p. 620). Children brought from the tundra to the boarding schools, who were used 
to the use of urine for washing (Bogoras 1904, p. 40) as well as for other household practices (e.g. hide and fur tanning), had to adapt to the daily use of water for washing and cooking.

The social sophistication, the creation of a new Soviet man, was propagated even by the art elite (e.g. film maker Dziga Vertov) ${ }^{20}$ all over the country, and equally among ethnic Russians. In the native context, however, both russification and sovietisation involved cultural hegemony over local sensory models inducing the feeling of ethnic inferiority among the colonised group. In relation to olfaction, the inferiority and stigmatisation of the natives were substantiated through "the interflow of explicit and implicit awareness of the stigma ascribed to the odour and the sentiments and actions to which this awareness gives rise" (Yamin-Pasternak et al. 2014, p. 626). Yamin-Pasternak et al. label this relationship "panolfacton" (referring to Michel Foucault's "panopticon" 1995 [1975], p. 201) to describe "the immutability and pervasiveness attributed to things that 'smell"' (Yamin-Pasternak et al. 2014, p. 620). Panolfacton is equally a by-product and a structuring element of a colonially dictated (pre-Soviet and Soviet) modernisation setting.

The social categorisation induced by such setting can be easily manipulated through the odours and the emotions attached to them. In fact, such context would not be possible unless power was exerted of moral and emotional categories-what is acceptable/inacceptable, pleasing/disagreeable, etc. Emotions can be easily linked with odours by association, such as, for instance, stench - feeling of disgust (Kirk-Smith \& Booth 1987; Robin et al. 1999). As Constance Classen contends: "The strong emotional appeal of smell [that] makes odours useful for classifying others", and even more so "the fact that it can be perceived at a distance and does not require intimate contact to be experienced" (Classen 1992, p. 160). Olfactory group differentiation, however, has been a practice equally conducted by the natives, yet from the position of the inferior group. The natives perceive the major differences when contrasted with the "incomers" (Yup.lyalyuromki). Incomers from outside Chukotka bring the smell of inland provisions, perfumes, and urbanised life. Before the 2000s, the distinction even among the local non-natives was mainly on the grounds of daily perfumery; nowadays, the use of perfumes, although often without any special competence or awareness, is equally popular among the locals and so the distinctions of body odours are subtler.

A vivid difference related to the body odour that still persists in the locals' perception concerns the incomers' arrival to the tundra. Such incomers are perceived by the natives as stinky and sweaty. One man recalled such encounter with an incomer who visited his tent; the native man got so sick that he had to leave the place and get some fresh air. According to his naïve explanation, the difference was caused by the diet high in the protein of people living in the tundra (Rus. tundroviki), more acidic stomachs and thus less bad smelling sweat. He adds that those incomers who had worked in the tundra for some time, gradually adapted to the diet and place and began to smell acceptably ${ }^{21}$. Odour, no matter whether it is consciously or unconsciously perceived, is vital information that signals our attachment or aversion to other people. Among the indigenous people of Chukotka, the marker of trust is encoded through odours by the mutual sniffing of the cheeks, usually practiced as a way of saying hello or good-bye.

31 Apart from social categorisation, body odours play an important role in the selfperception of the natives. Framed in the colonised setting, the notion of the "savage man" (Rus. dikar') well-known to the natives, through schooling, literature and public 
discourse, provides a source of signs to create the different modalities of identities and affiliations. The non-indigenous imagery (a set of images and mental representation) of the "savagery" often serves the natives as a hint of how to reconstruct the indigenous sense of belonging. This happens in the formal contexts, such as the event management of the International Day of the World's Indigenous Peoples (designated by the United Nations on $9^{\text {th }}$ August each year), conducted by the local Administration office. Equally so, it is a part of informal everyday life situations, often as a self-confirmative claim with irony or jibe "Yes, I am a savage man". It seems as if the natives had dug out from these imageries the virgin indigenous man who was supposed to be there "before ethnology" (Baudrillard 1984, p. 253).

The image of a man who takes risks and survives severe conditions, "still living in the cradle of the race" like in Robert Flaherty's film Nanook of the North (1922), is still preserved. This notion is mirrored in the olfactory code of adrenaline. Local men experienced in hunting often distinguish themselves from others in the hunting stories by saying that they do not show fear and, therefore, animals, do not dare to attack them. In contrast, people say the odour of adrenaline due to fear signals a lack of experience and such an unskilled hunter can be easily attacked or even killed by an animal. Today, however, anything related to risk or stress falls under this odour category of adrenaline. It can be conceived as an unpleasant smell with negative connotations in the context of a school exam; adrenaline marks the stress related to the possible outcome of the exam, success or failure. In contrast, even if perceived as unpleasant, the odour of adrenaline can excite and agitate, and thus be associated with positive emotions for the subject. One of my informants described the feeling of impunity he had in relation to the odour of adrenaline he could smell, while breaking into the local food stores in "the hungry 1990s" (Rus. golodnye devianostye) ${ }^{22}$. He was thrilled that his plan worked out, each element fitted together like in a puzzle. The excitement was intensified by the odours of the reward that awaited him in the store: clothes, sweets, perfumes, all the things his parents could not buy him and he could just choose anything he wanted. For others, the hungry 1990s are associated with other kind of hazardous behaviour. The easiest and fastest way to make money was to sell incomers caviar. A number of natives would fish just to get the caviar, throwing the dead fish all over the shores and leaving them to rot and smell. My informant recalls helicopters flying here and there all the time for this caviar business, stirring up the smell of rotten fish and men's booze breath (the money for caviar was often used to purchase alcohol).

A peculiar body odour that has been problematised ${ }^{23}$ emic-ally and is especially associated with the dramatic increase of alcohol consumption in 1990s, is "booze breath" (Rus. peregar). It is the reek of alcohol; much more than alcohol abuse itself, that provokes negative sentiments, rejection, embarrassment, or shame. As one of my informants claimed: "I don't like the smell of alcohol. Not because I abused and now [trying to stay sober] it would recall something to me, or that kind of shit. I never liked it. I did not abuse, because I didn't like it". The smell is omnipresent and cannot be easily subdued or covered. Whatever one eats by drinking, even an expensive chocolate, as one informant stated, the smell of alcohol is always equally unpleasant. I witnessed how a man ate "whale blubber" (Yup. mantak') and onion deliberately before a date, in order to get rid of the unpleasant smell of alcohol, acquiring another strongly odour, yet socially more acceptable. This awareness of olfactory acceptance or rejection translates into various practices of self-grooming. What is more important, however, 
such attention towards own body odours transcends etiquette. Even in a community where alcoholism is so pervasive (across the ethnic-, gender-, age groups, transgressing public and public spaces) and is equally associated with the non-natives ("They brought the alcohol here!" "They abuse, too!" - say some natives about incomers), an attempt to cover its olfactory marker in interethnic contact points to the avoidance of the possible stigma. There is an emic awareness that this olfactory code distracts any imagery of indigenous tradition and defines the pejorative association of the natives with stench.

Another cultural artefact that combines olfactory codes, saturates emotions and the notion of belonging is animal fur. The sentiments might be both negative and positive. For instance, a former reindeer herder who now lives in the city recalled the happy moments of his childhood: as a child he would take the reindeer with his Dad and he would lean on his Dad's back; when he felt cold, he would plunge his freezing nose into his Dad's spine to get warmer.

Another example illustrates the redefinition of the sense of belonging through the body odour mixed with animal odours peculiar to the native land. A young girl told me the story of how she once participated in a folk-dance festival in her native village. Having followed the instruction of her teacher and mother, she dressed up in a dance costume made of a reindeer hide. It was supposed to be more authentic than a costume made of a regular cotton fabric. However, the hide, according to traditional techniques, was impregnated with human urine. During the performance the young girl sweated, which even enhanced the original odour of the hide. Once the show was over, the girl, as she said, ran away from the stage and hastily shook the costume off her. Had she told me the story in her native village, she would probably have highlighted her embarrassment of the awkward costume and the absurd situation when she, as a teenager, followed the adults' rules and pretended to be someone other than who she actually was. However, she told me the story while studying in Saint Petersburg, thousands of kilometres from home, trying to adapt to a culturally different setting. She was in the phase when she repudiated her home and reject where she comes from in order to be able to accept the otherness of the new place. Consequently, she pinpointed the negative feelings about her home through the most expressive markers - olfactory codes. The girl preserved a vivid memory of disgust evoked by the fur macerated in urine and soaked with her sweat. No matter what the source of odorous sensation was objectively like (aromatic molecules), here the olfactory code acts as intersubjective mental representation of the aromatic stimuli made possible by the sense of olfaction. The young girl describes the odour by its source - she assumes that I, as a foreigner, living in the city, also perceives the smell of reindeer urine disgusting, or at least, repelling). She is also aware of the effect the olfactory stimuli supposedly have in relation to her - she ascribes her cultural origin the same smell of urine and declares "my culture stinks". Both, the link between the odour and the effect as well as the link between the effect and emotion are learnt. The negative connotation behind the effect might stem up from the interaction with the non-natives at home; later, it is accentuated in the city. This assault of the obsolete and estranged animal body on a young intimate girl's self, as the young girl perceives it, is an example of how large-scale processes, such as cultural adaptation or institutional framing, can be traced in individual's intimate experience.

36 The memory framed in this way has another aspect to it. Not just the traditional dance costume but her cultural experience from home was perceived by the girl as obsolete, 
repugnant, and offensive. These sentiments were linked with the odour of repulsive stench. In the further account, she elaborated on some other aspects of life at home that she perceived negatively (e.g. alcoholism and unemployment). Thus, she tried to frame her previous cultural experience in such a manner that would allow her to more easily let go of her past (for the time being or once for all). The olfactory code in this example marks a singular memory of personal displacement: young girl from a Chukotka hamlet wishes to adapt to Saint Petersburg city through rejecting her origin. In certain smells, she finds a synecdoche for the critical interpretation of the notion of "my native culture". The stench of the costume (negative olfactory code) is here synonymised with the sense of belonging that is, in turn, associated with an awareness of being inferior.

37 I will argue that even under the given circumstances the natives do not deodorise the sense of belonging. Rather, everyday practices show a layering of various olfactory modalities, some perceived as native, some of non-native origin. The actual practices of many Soviet and post-Soviet institutions, such as libraries, schools and hospitals correspond to sanitation-institutionalised system of hygiene maintenance; deodorisation is its side product. One of the routines is thorough clean-up, and precaution inspection in a particular time during the day or within a month. This Sanitary break or Sanitary Day represents an institutionalised attempt to synthesise the appearance of cleanliness, positive olfactory codes and civility. In the native context, sanitation occurs also in the private spaces. Let us look at some examples of the olfactory experience in the households.

\section{Hearth and home}

Modernisation introduced a notion of domesticity. Although, Soviet state practices devalued the private sphere as antisocial and individualistic (Pine 2017), it still represented the centre for trust, practical kinship, and social relatedness (Buzalka \& Ferencová 2017, p. 160). Here I aim to give several examples of sociocultural dynamics that take place at the intersection of the olfactory codes and the sense of home. The term "home" is used here in its two meanings of the lingua franca of the field site, i.e. Russian language; in the literal meaning - as a house or residence -, and in the abstract meaning - as a sense of belonging somewhere, including a sense of origin, roots, and cultural background. Looking at social transitions, one of the most apparent olfactory alterations that occurs in the liminalities, are the odorous encounters on the door sill of the house.

Prior to the Soviet era, Bogoras (Bogoras 1904, pp. 38-40) described some taboo related to the odours and the house: it was unacceptable to bring anything from other households to the inner "sleeping room" (Rus. polog) due to its unfamiliar odours. I witnessed the same in 2014 in a modern house, but with the explanation that my physical presence as a foreigner, including my body odour, might disturb the spirits of the home. Bogoras noted that the locals rejected unfamiliar odours of medicines, wild onions, and an archival document (to the point that the housekeeper fainted), but accepted the odours of the books or provisions (canned meats, fruit, vegetables, sugar) the ethnographer brought with him (Bogoras 1904, pp. 38-39). Similarly, people who were suffering from syphilis were not allowed to enter clean camps, as "[...] the odour 
of their hearth and the shadow of their entrance might prove infectious to their neighbours" (Bogoras 1904, p. 40).

Olfactory imagery related to the domestic place is, therefore, quite broken, unsettled. Before the general rebuilding of the hamlet in the early $2000 \mathrm{~s}^{24}$, the village was associated with the smell of smoke, as each house, even the Soviet block of flats, had a fire stove. For people living in the tundra, the smell of the village or hamlet was considered foreign. One former reindeer herder explained that he needed to adapt to the smells of the hamlet every time he came from the tundra: even if empty for a long time, the barrels placed on the borders of the village gave off a strong unpleasant smell of gas. Apart from gas exhaust and chemical substances, he also associated the hamlet with the odour of a crowded dorm school. The intensity of the odours of his numerous classmates and teachers changed his olfactory capacity, as he felt: "it became dull". In contrast, the tundra is still imagined by him as an open space that allows easy breathing. If people who live and work in tundra are inclined not to pay so much attention to the odours of the fast-changing flora in the summer, for the people settled in villages this smell brings up very vivid and positive memories. The latter consider actual smells of a house significant; these are especially women, who find themselves homey and seek comfort in domesticity, handicrafts and cuisine.

Before electricity was introduced among the Chukotka in the early Soviet times, the "tents" (Rus. yaranga) were heated and lighted with oil lamps fuelled by whale fat. Its smell must have brought home not just the odour, but the taste of a favourite food. The detailed olfactory portrayal of the modern Yupik house from the point of view of native cuisines is given by Yamin-Pasternak et al. (2014). These authors also analyse the implications that the fragrant food has for social differentiation, especially for the relationship between the natives and the others configured by the colonised modernisation setting. Here I aim to limit myself to one practice that is related to fragrant food, but that demonstrates the complicated differentiation within the local group; beside the persistent significance of the lineage and clan systems ${ }^{25}$, the natives hierarchise themselves according to the patterns often imposed by the values, moralities, and aspirations of the superior group, ethnic Russians. This is vivid through the practices labelled "progressive" (Rus. prodvinutye) that mirror the concept of civility and sanitation mentioned earlier. Let me mention this example.

I witnessed this behavioural pattern ${ }^{26}$ : a family that owns four houses - the mother and two sons reside together in one house, while two daughters with their own families and one unmarried daughter reside in the other three houses. They coordinate family gatherings and eating according to the type and odour of the cuisine offered. The native food is prepared and consumed in the house of the oldest family member (mother) and/or the person whose occupation is considered "traditional", i.e. sea mammal hunting (one of the two brothers is a hunter). Fragrances that elsewhere could be perceived as offensive are taken as fitting, appropriated, "ours". One daughter who works in the housing maintenance service cohabits with a sea mammal hunter; here the cuisine is mixed and the consumption of some less fragrant native cuisine is completely acceptable. Two other houses are kept clean of the local cuisine. Especially the oldest daughter, a single schoolteacher, demonstrates through her house her family's aspirations for a home she considers "modern" (Rus. sovremennyj, urban-like, hip, fashionable, prevalent): new sofa, large carpet, curtains and inbuilt closet are perfected by the embroidered souvenirs handcrafted by local native women mingle 
with the Soviet-style glass cupboard with diploma, photos, and china, an "American" coffee maker brought from Alaska.

This example also shows the range of olfactory distinctions related to the house which involve the redefinition of "who I am", "how I should be", "how others should see me". The category "traditional" is negotiated here on many different levels; when fuelled by the superior discourse (represented by the non-natives, mostly ethnic Russians, incomers), the category tends to be synonymous with "backward", "uncivilised" ${ }^{27}$. At the same time, it mirrors urban - rural differentiation. The native locals often alternate between the desire to do certain things just like the non-natives do (i.e. they wish to be "with it", educated, materially well) and the desire to not look like them (e.g. they romanticise native special connection with nature in contrast to non-natives' loss of it). Being like a non-native still implies too many additional negative qualities that may lead to exclusion from the "insiders' group". On the contrary, such attributions as "advanced", "not savage", "civilised", "modern" are positive definitions created by "the non-native".

The local people (both natives and non-natives) associate these labels with the cleanliness of the house. Since odours are the first stimuli sensed at the door-step, it becomes the primary code that represents cleanliness while also standing for "progress" (Rus. prodvinutost'), as the local natives claim. In other words, the code in this case is linked with a pleasant or neutral odour, while excluding any smells that could be considered "bad". Local people with traditional occupations and fewer private contacts with non-natives can prepare local meals directly in their house. The odours that accompany such preparation and consumption do not offend any native; they go hand in hand with the image of a sea mammal hunter's lifestyle. The natives who aspire for high social status within the broader society have ceased to prepare fragrant native cuisine in their homes. At the same time, many of them refuse to avoid food which they find tasty, even if the referential authority, the non-natives, would find it disagreeable. The involvement of the whole family in the process of coordinating spaces for different meals, various olfactory codes, and social affiliations is, thus, absolutely vital.

\section{Conclusion}

My attempt in this study was to give an account of a few olfactory practices that reveal a complex tapestry of social, cultural, political, and certainly sensory dynamics. I tried to approach the local olfactory practices in Russian Beringia on the emic sensory terms. These examples illustrate the significant role olfaction plays in the lives of the local people, in particular in the negotiation of the sense of belonging. The questions, such as "where is my place?", "what is my home?", "what is my culture?" or "where do I belong?" are addressed in the context of the changing social and sensory regimes of the Soviet and post-Soviet modernisation. Some odours are selected by the locals to encode the negative perception of those cultural patterns that seem to these social actors, especially in interaction with- and/or reference to outer groups, unacceptable, obsolete or unnecessary. In turn, these odours are then loaded with negative emotions, such as anxiety, rejection, or disgust. This can point to the significant changes taking place in the cultural configuration.

At the same time, I argue that even such olfactory coding can be situational; the newly acquired negative meaning of certain odours does not and cannot completely eliminate 
their sources (and effects) from people's lives. The management of olfactory cues seems to be conducted in self-reflective manner, but at the same time with great awareness of the reaction of other participants to the situation (be it other natives, local nonnatives, or incomers). Various examples of olfactory behaviours show common emotional patterns, such as enjoyment, nostalgia, awareness, and ambivalence according to the given settings. The capacity of olfactory models to create social differentiation, thus, depends heavily on the situational negotiations of the forms of everyday objects and practices. Instead of fixed forms within precise configurations of community and context (in contrast to highly conventionalised cultural production at the House of Culture, see Donahoe \& Habeck 2011), the olfactory encoding seems to be much more complex than a simple narrative of Soviet deodorisation and the postSoviet return to some ethnically/culturally distinct olfactory codes. Instead of deodorisation, people consider, test and implement certain sanitary behavioural models into everyday routines.

Such look at the forms of expression, sensibility, and community generated by the Soviet modernisation in Chukotka (and even broadly, in Arctic Russia) can shed light on the distinctive olfactory models. Olfactory experience sustained with emotions, in turn, seems to condition the ways, range and depth the Soviet (and post-Soviet) policies were implemented into the lives of the native peoples of Chukotka. The inconsistency of this process reveals how crucial it is for the anthropology of continuity and change to look at sensory models as an alternative scope of its focus. Chaney's work on lifestyles (Chaney 1996) can be a relevant theoretical model in the way it frames the issue of expressive behaviours and social differentiation; in this sense, it is interpreted here through the sensory aesthetic in Chukotka. I suggest that it can be further explored in comparative studies related to contemporary Arctic Russia. The study demonstrates that olfactory experience sustained with emotions are vital conditions of social order, especially, when the social regimes seem to be unstable or ambivalent; the focus on the sensory models can be a pathway that opens up new possibilities of understanding social differentiation, conflict, and possibly, integration.

\section{Acknowledgements}

This research was supported from public sources by the Slovak Research and Development Agency (contract number APVV-14-0431; Faculty of Social and Economic Sciences, Comenius University in Bratislava) and by the Slovak Arts Council (individual stipend).

49 My gratitude belongs to Professor Dr. Igor L. Nabok, PhD., Svetlana Chernyshova, PhD. and the Institute of the peoples of the North - Herzen State Pedagogical University of Russia, Saint Petersburg as well as to my numerous informants of Chukotka. 


\section{BIBLIOGRAPHY}

All-Russian Population Census 2010 Federal State Statistics Service of the Russian Federation [online, URL: http://www.gks.ru/free_doc/new_site/perepis2010/croc/perepis_itogi1612.htm, accessed 9 February 2019].

Ayabe-Kanamura, S., I. Schicker, M. Laska, R. Hudson, H. Distel, T. Kobayakawa \& S. Saito 1998 Differences in perception of everyday odors. A Japanese-German cross-cultural study, Chemical Senses 23, pp. 31-38.

Appadurai, A. (ed.) 1986 The Social Life of Things. Commodities in Cultural Perspective (Cambridge, Cambridge University Press).

Bagdasarova (Panakova), J. 2012 Sense of distant hereness. Making and unmaking oneself at home (case of Chukchi and Yupik), in E. Filippova (ed.), Twenty Years Later 1991-2011. The Reshaping of Space and Identity (Moscow, Russian State University for the Humanities), pp. 185-197.

Barkat-Defradas, M. \& E. Motte-Florac (eds) 2016 Words for Odours. Language Skills and Cultural Insights (Cambridge, Cambridge Scholars Publishing).

BAudrillard, J. 1984 Precession of simulacra, in B. Wallis (ed.) Art after Modernism. Rethinking Representation (New York, MOMA), pp. 253-281.

Beatty, A. 2005 Emotions in the field. What are we talking about?, Journal of the Royal Anthropological Institute 11(1), pp. 17-37.

Beauchamp, G. K. \& J. A. Mennella 2011 Flavor perception in human infants. Development and functional significance, Digestion 83(1), pp. 1-6.

Beer, B. 2000, Geruch und Differenz. Körpergeruch als Kennzeichen konstruierter „rassischer“ Grenzen, Paideuma 46, pp. 207-230.

2007 Smell, person, ppace and memory, in K. Stockhaus \& J. Wassmann (eds), Person, Space and Memory in the Contemporary Pacific (New York/Oxford, Berghahn), pp. 187-200.

2014 Boholano olfaction. Odour terms, categories and discourses, The Senses and Society 9(2), pp. 151-173.

Bigelow, C. 1992 Presenting the self, the social body, and the olfactory. Managing smells in everyday life experiences, Sociological Perspectives 49, pp. 607-631.

Bogoras, W. 1904 The Chukchee, part. 1, Material Culture (New York, AMS Press, Memoirs of the American Museum of Natural History 11).

Bourdieu, P. 1984 Distinction. A Social Critique of the Judgement of Taste, translated by R. Nice (London, Routledge).

Bull, M. \& L. Black (eds) 2003 The Auditory Culture Reader (Oxford, Berg).

Burenhult, N. \& A. Majid 2011 Olfaction in Aslian ideology and language, Senses \& Society 6(1), pp. 19-29.

Buzalka, J. \& M. Ferencová 2017 Workers and populism in Slovakia, in S. Narotzky \& V. Goddard, Work and Livelihoods. History, Ethnography and Models in Time of Crisis (London, Routledge), pp. 157-171.

Candau, J. 2000, Mémoire et expériences olfactives. Anthropologie d'un savoir-faire sensoriel (Paris, PUF). 2001 De la ténacité des souvenirs olfactifs, La Recherche 344, pp. 58-62. 
2007 Partager des odeurs “à ne pas regarder". Sociotransmetteurs, langage et émotions, VOIR 34, pp. 33-46.

2013a Une théorie sensorielle de l'identité, in P.-L. Colon (ed.), Ethnographier les sens (Paris, Éditions Petra), pp. 201-234.

2013b Le cadavre en substance. Perte d'odeurs et principe vital, Techniques \& Culture 60(1), pp. 110-125.

2016 L'anthropologie des odeurs. Un état des lieux, Bulletin d'études orientales 64(1), pp. 43-61.

Candau, J. \& A. Jeanjean 2006 Des odeurs à ne pas regarder..., in Odeurs, special issue, Terrain 47, pp. 51-68.

Candau, J. \& O. Wathelet 2011 Les catégories d'odeurs en sont-elles vraiment ?, Langages 181(1), pp. 37-52.

Chaney, D. 1996 Lifestyles (London/New York, Routledge).

Chrea, Ch., D. Valentin \& H. Abdi 2009 Graded structure in odour categories. A cross-cultural case study, Perception 38(2), pp. 292-309.

Classen, C. 1992 The odor of the other. Olfactory symbolism and cultural categories, Ethos 20(2), pp. 133-166.

1993 Worlds of Sense. Exploring the Senses in History and Across Cultures (London/New York, Routledge).

(ed.) 2005 The Book of Touch (Oxford/New York, Berg).

Classen, C., D. Howes \& A. Synnott 1994 Aroma. The Cultural History of Smell (London, Routledge).

Corbin, A. 1982 Le miasme et la jonquille (Paris, Flammarion).

1986 The Foul and the Fragrant. Odor and the French Social Imagination (Cambridge MA, Harvard University Press).

Croijmans, I. \& A. Majid 2016 Not all flavor expertise is equal. The language of wine and coffee experts, PLoS One 11(6), e0155845.

Csordas, T. (ed.) 1994 Embodiment and Experience. The Existential Ground of Culture and Self (Cambridge, Cambridge University Press).

David, S. 2002 Linguistic expressions for odors in French, in C. Rouby, B. Schaal, D. Dubois, R. Gervais \& A. Holley, Olfaction, Taste, and Cognition (Cambridge, Cambridge University Press), pp. 100-116.

David, S., D. Dubois, C. Rouby \& B. Schaal 1997 L'expression des odeurs en français. Analyse lexicale et représentation cognitive, Intellectica 24, pp. 51-83.

Donahoe, B. \& O. Habeck (eds) 2011 Reconstructing the House of Culture. Community, Self, and the Makings of Culture in Russia and Beyond (New York, Berghahn).

Douglas, M. 1975 Deciphering a Meal, in Implicit Meanings. Essays in Anthropology (London, Routledge and Kegan Paul), pp. 231-251.

Dulau, R. 1998 Exploration du champ du senti à Pondichéry, in R. Dulau \& J.-R. Pitte (eds), Géographie des odeurs (Paris, L'Harmattan), pp. 81-118.

Dubois, D. \& C. Rouby 2002 Names and categories for odors. The veridical label, in C. Rouby, B. Schaal, D. Dubois, R. Gervais \& A. Holley, Olfaction, Taste, and Cognition (Cambridge, Cambridge University Press), pp. 47-65.

Erlmann, V. (ed.) 2004 Hearing Cultures. Essays on Sound, Listening and Modernity (Oxford, Berg). 
Faurion, A., B. Cerf, A.-M. Pillias, N. Boireau 2002 Increased taste sensitivity by familiarisation to novel stimuli. Psychophysics, fMRI, and electrophysiological techniques suggest modulations at peripheral and central levels, in C. Rouby, B. Schaal, D. Dubois, R. Gervais \& A. Holley, Olfaction, Taste, and Cognition (Cambridge, Cambridge University Press), pp. 350-366.

Flaconneur 2015 Just who is Christopher Brosius?, in PER FUMUS. A journey of the senses by Flaconneur, blog [online, URL: https://perfumuschicago.wordpress.com/2015/02/07/just-who-ischristopher-brosius/, accessed 5 May 2018].

Flaherty, R. 1922 Nanook of the North, film (distr. Pathépicture, USA), 79 minutes | 35 mm.

Foucault, M. [1975] 1995 Discipline and Punish. The Birth of the Prison (New York, Vintage).

Gell, A. 1977 Magic, perfume, dream, in I. M. Lewis (ed.), Symbols and Sentiments. Cross-Cultural Studies in Symbolism (London, Academic Press), pp. 25-38.

Gilbert, A. N. 2008 What the Nose Knows. The Science of Scent in Everyday Life (New York, Crown).

Gray, P. A. 2005. The Predicament of Chukotka's Indigenous Movement. Post-Soviet Activism in the Russian Far North (Maynooth, National University of Ireland).

Grimshaw, A. 2001 The Ethnographer's Eye. Ways of Seeing in Anthropology (Cambridge, Cambridge University Press).

Habeck, J. O. (ed.) 2019 Lifestyle in Siberia and the Russian North (Cambridge, Open Book Publishers). Holley, A. 1999 Éloge de l'odorat (Paris, Odile Jacob).

Howes, D. 1987 Olfaction and transition. An essay on the ritual use of smell, Canadian Review of Sociology/Revue canadienne de sociologie 24(3), pp. 398-416.

2002 Nose-wise. Olfactory meta, in C. Rouby, B. Schaal, D. Dubois, R. Gervais \& A. Holley, Olfaction, Taste, and Cognition (Cambridge, Cambridge University Press), pp. 67-81.

2003 Sensual Relations. Engaging the Senses in Culture and Social Theory (Ann Arbor, MI, University of Michigan Press).

2006 Empire of the Senses. The Sensual Culture Reader (Oxford, Berg Publishers).

Howes, D. \& C. Classen 2014 Ways of Sensing. Understanding the Senses in Society (London N.Y., Routledge).

Huang, X. 2016 Deodorizing China. Odour, ordure, and colonial (dis)order in Shanghai, 1840s-1940s, Modern Asian Studies 50(3), pp. 1092-1122.

Hudson, R. \& H. Distel 2002 The individuality of odor perception, in C. Rouby, B. Schaal, D. Dubois, R. Gervais \& A. Holley, Olfaction, Taste, and Cognition (Cambridge, Cambridge University Press), pp. 408-420.

Hughes, J. 1996 Stalinism in a Russian Province. Collectivization and Dekulakization in Siberia (London, Palgrave).

Hussain, A., L. R. Saraiva, D. M. Ferrero, G. Ahuja, V. S. Krishna, S. D. Liberles \& S. I. Korsching 2013 High-affinity olfactory receptor for the death-associated odor cadaverine, Proceedings of the National Academy of Sciences 110(48), pp. 19579-19584.

Illich, I. 2000 The dirt of cities, the aura of cities, the smell of the dead and utopia of an odourless city, in M. Miles, T. Hall \& I. Borden (eds), The City Cultures Reader (London, Routledge), pp. 249-252.

Jacknis, I. 1984 Franz Boas and Photography, Studies in Visual Communication 10(1), pp. 2-60. 
Jenner, M. S. R. 2000 Civilisation and deodorisation? Smell in early modern English culture, in P. Burke, B. Harrison \& P. Slack, Civil Histories. Essays Presented to Sir Keith Thomas (Oxford, New York, Oxford University Press), pp. 127-144.

2011 Follow your nose? Smell, smelling, and their histories, The American Historical Review 116(2), pp. 335-351.

Jolles, C. Z \& E. M. Oozeva 2002 Faith, Food and Family in a Yupik Whaling Community (Seattle, University of Washington Press).

Kirk-Smith, M. D. \& D. A. Booth 1987 Chemoreception in human behaviour. Experimental analysis of the social effects of fragrances, Chemical Senses 12(1), pp. 159-166.

Korsmeyer, C. 2005 The Taste Culture Reader. Experiencing Food and Drink, English ed. (Oxford, New York, Berg).

Köster, E. P. 2002 The specific characteristics of the sense of smell, in C. Rouby, B. Schaal, D. Dubois, R. Gervais \& A. Holley, Olfaction, Taste, and Cognition (Cambridge, Cambridge University Press), pp. 27-43.

Kotkin, S. 1995 Magnetic Mountain. Stalinism as a Civilization (Berkeley/Los Angeles, University of California Press).

Kozlov, A., V. Nuvano \& G. Vershubsky 2007 Changes in Soviet and Post-Soviet indigenous diets in Chukotka, Études Inuit Studies 31(1-2), pp. 103-119.

Krupnik, I. 2000 Pust' govoriat stariki. Rasskazy aziatskikh eskimosov-yupik. Zapisi 1975-1987gg [Let our elders talk. Stories of the Yupik/Asiatic Eskimos recorded in 1975-1987] (Moscow, Russian Institute of Cultural and Natural Heritage).

Krupnik, I. \& M. Chlenov 2013 Yupik Transitions. Change and Survival at Bering Strait, 1900-1960 (Fairbanks, University of Alaska Press).

Lambek, M. 1981 Human Spirits. A Cultural Account of Trance in Mayotte (Cambridge, Cambridge University Press).

Le Guérer, A. 2002 Olfaction and cognition. A philosophical and psychological view, in C. Rouby, B. Schaal, D. Dubois, R. Gervais \& A. Holley, Olfaction, Taste, and Cognition (Cambridge, Cambridge University Press), pp. 3-15.

Leenhardt, M. 1979 Do Kamo. Person and Myth in the Melanesian World (Chicago, University of Chicago Press).

Lévi-Strauss, C. 1955 Tristes tropiques (Paris, Plon).

Low, K. E. Y. 2006 Presenting the self, the social body, and the olfactory. Managing smells in everyday life experiences, Sociological Perspectives 49, pp. 607-631.

2009 Scents and Scent-sibilities. Smell and Everyday Life Experiences (Cambridge, Cambridge Scholars Publishing).

Majid, A. \& N. Burenhult 2014 Odors are expressible in language, as long as you speak the right language, Cognition 130(2), pp. 266-270.

Majid, A. \& N. Kruspe 2018 Hunter-gatherer olfaction is special, Current Biology 28(3), pp. 409-413.

Majid, A., L. Speed, I. Croijmans \& A. Arshamian 2017 What makes a better smeller? Perception 46, pp. 406-430.

Mariani, L. 2015 L'exotisme et le fruit de l'imagination. Le-durian-qui-partage-l'humanité-endeux, Anthropologie et Sociétés 39(1-2), pp. 313-328. 
Michelson, A. (ed.) 1984 Kino-Eye. The Writings of Dziga Vertov (Berkeley/Los Angeles/London, University of California Press).

Miller, D. (ed.) 1991 Acknowledging Consumption. A Review of New Studies (London/New York, Routledge).

Myers, C. S. \& W. McDougall 1903 Hearing, smell, taste, cutaneous sensations, etc., in A. C. Haddon (ed.), Reports of the Cambridge Anthropological Expedition to the Torres Straits, vol. 2, part 1 (Cambridge, Cambridge University Press).

Pine, F. 2017 Lost generations? Unemployment, migration and new knowledge regimes in post EU Poland, in S. Narotzky \& V. Goddard, Work and Livelihoods. History, Ethnography and Models in Time of Crisis (London, Routledge), pp. 31-45.

Pink, S. 2006 The Future of Visual Anthropology. Engaging the Senses (London/New York, Routledge).

Ponty, J. 1995 Les Polonais du Nord ou la mémoire des corons (Paris, Autrement).

Porcello, T., L. Meintjes, A. M. Ochoa, D. Samuel 2010 The reorganisation of the sensory world, Annual Review of Anthropology 39, pp. 51-66.

Prokop-Prigge, K A., K. Greene, L. Varallo, C. J. Wysocki, G. Preti 2016 The effect of ethnicity on human axillary odorant production, Journal of Chemical Ecology 42, pp. 33-39.

Ravel, N., A.-M. Mouly, P. Chabaud \& R. Gervais 2002 Experience-induced changes reveal functional dissociation within olfactory pathways, in C. Rouby, B. Schaal, D. Dubois, R. Gervais \& A. Holley, Olfaction, Taste, and Cognition (Cambridge, Cambridge University Press), pp. 335-349. Rodaway, P. 1994 Sensuous Geographies. Body, Sense and Place (London/New York, Routledge).

Robin, O., O. Alaoui-Ismaïli, A. Dittmar \& E. Vernet-Maury 1999 Basic emotions evoked by eugenol odor differ according to the dental experience. A neurovegetative analysis, Chemical Senses 24(3), pp. 327-335.

Roubin, L. A. 1989 Le monde des odeurs (Paris, Méridiens Klincksieck).

Rouby, C. \& M. Bensafi 2002 Is there a hedonic dimension to odors?, in C. Rouby, B. Schaal, D. Dubois, R. Gervais \& A. Holley, Olfaction, Taste, and Cognition (Cambridge, Cambridge University Press), pp. 140-159.

Rouby, C. \& G. Sicard 1997 Des catégories d'odeurs, in D. Dubois (ed.), Catégorisation et cognition. De la perception au discours (Paris, Edition Kimé), pp. 59-81.

Schaal, B. (ed.) 1997 L'odorat chez l'enfant. Perspectives croisées, special issue, Enfance 1.

Schaffer, E. S., D. D. Stettler, D. Kato, G. B. Choi, R. Axel \& L. F. Abbott 2018 Odor perception on the two sides of the brain. Consistency despite randomness, Neuron 98(4), pp. 736-742.

Searles, E. Q. 2002 Food and the making of modern Inuit identities, Food and Foodways 10(1-2), pp. 55-78.

2016 The raw, the cooked and the fermented. The culinary heritage of foragers, past and present, in D. J. Timothy (ed.), Heritage Cuisines. Traditions, identities and tourism (London, Routledge), pp. 25-36.

Shepard, G. H. 2004 A sensory ecology of medicinal plant therapy in two Amazonian societies, American Anthropologist 106, pp. 252-266.

Slezkine, Y. 1994 Arctic Mirrors. Russia and the Small Peoples of the North (Ithaca, Cornell University Press). 
Sorokowska, A., P. Sorokowski, T. Hummel \& T. Huanca 2013 Olfaction and environment. Tsimane' of Bolivian rainforest have lower threshold of odor detection than industrialised German people, PLoS One 8(7), e69203.

Speed, L. J. \& A. Majid 2018 Superior olfactory language and cognition in odor-color synaesthesia, Journal of Experimental Psychology. Human Perception and Performance 44(3), pp. 468-481.

Sperber, D. 1975 Rethinking Symbolism (Cambridge, Cambridge University Press), pp. 115-149.

Spray, Z. 2002 Alaska's vanishing Arctic cuisine, Gastronomica 2(1), pp. 30-40.

Spray Starks, Z. 2007 Arctic foodways and contemporary cuisine, Gastronomica. The Journal of Food and Culture 7(1), pp. 41-49.

2011 Drying and fermenting in the Arctic. Dictating women's roles in Alaska's Iñupiat culture, in H. Sabieri (ed.), Cured, Fermented and Smoked Foods. Proceedings from the Oxford Symposium on Food and Cookery 2010 (Devon, Prospect Books), pp. 302-311.

Stewart, S. 1999 Prologue. From the Museum of touch, in M. Kwint, Ch. Breward \& J. Aynsley, Material Memories. Design and Evocation (Oxford/New York, Berg), pp. 17-36.

Stoller, P. 1989 The Taste of Ethnographic Things. The Senses in Anthropology (Philadelphia, University of Pennsylvania Press).

Sutton, D. E. 2010 Food and the senses, Annual Review of Anthropology 39, pp. 209-223.

Synnott, A. 1991 A sociology of smell, Canadian Review of Sociology/Revue canadienne de sociologie 28(4), pp. 437-459.

Vainshtein, 0. 2003 Aromaty i zapahi v kul'ture [Fragrances and odours in culture] (Moscow, Novoe literaturnoe obozrenie).

Van Beek, W. E. A. 1992 The dirty Smith. Smell as a social frontier among the Kapsiki/Higi of North Cameroon and North-Eastern Nigeria, Africa. Journal of the International African Institute 62, pp. 38-58.

Wnuk, E. \& A. Majid 2012 Olfaction in a Hunter-Gatherer Society: Insights from Language and Culture, in N. Miyake, D. Peebles, and R. P. Cooper (Eds.), Proceedings of the $34^{\text {th }}$ Annual Meeting of the CogSci 2012 (Austin, Cognitive Science Society), pp. 1155-1160.

Yamin-Pasternak S., A. Kliskey, L. Alessa, I. Pasternak \& P. Schweitzer 2014 The rotten Renaissance in the Bering strait. Loving, loathing, and washing the smell of foods with a (re)acquired taste, Current Anthropology 55(5), pp. 619-646.

Yurchak, A. 2006 Everything Was Forever Until It Was No More. The Last Soviet Generation (Princeton, Princeton University Press).

\section{NOTES}

1. Just to give a few examples of the growing body of sensory literature: -hearing: Erlmann 2004; Bull \& Back 2003;

-haptics: Stewart 1999; Classen 2005;

-olfaction: Howes 2006; Synnott 1991; Bigelow 1992; Beer 2007, 2014; Burenhult \& Majid 2011; Classen 1992, 1993; Classen et al. 1994; Illich 2000; Low 2006, 2009; Wnuk \& Majid 2012;

-taste: Douglas 1975; Korsmeyer 2005;

-sensory synaesthesia: Porcello et al. 2010; Sutton 2010. 
2. Among others, there are philosophy and psychology (see Le Guérer 2002 for detailed review), history (Corbin 1986 ; Jenner 2000 ; Huang 2016), linguistics (David 2002 ; Dubois \& Rouby 2002; Majid \& Burenhult 2014; Barkat-Defradas \& Motte-Florac 2016; Speed \& Majid 2018; Majid \& Kruspe 2018), cognitive studies (Ravel et al. 2002), chemistry and chemical ecology (ProkopPrigge et al. 2016), neurobiology and physiology (Rouby \& Bensafi 2002; Faurion et al. 2002; Schaffer et al. 2018), biology and biopsychology (Beauchamp \& Mennella 2011), research on childhood (Schaal 1997), etc.

3. Cultural and ecological features have an impact on odour threshold sensitivities. For example, the Tsimané, indigenous people of Bolivian rainforest, detect n-butanol at significantly lower concentrations than people from Dresden (Sorokowska et al. 2013); the possible sources of such differences are: (i) the impact of pollution which impairs the olfactory abilities of people from industrialised countries; (ii) better training of olfaction because of the higher importance of smell in traditional populations; (iii) environmental pressures shaping olfactory abilities in these populations.

4. See Van Beek 1992; Classen 1993; Classen et al. 1994; Vainshtein 2003; Howes 2006; Howes \& Classen 2014.

5. Ayabe-Kanamura et al. 1998; Shepard 2004; Sorokowska et al. 2013.

6. Gilbert 2008; Yamin-Pasternak et al. 2014.

7. Among others, Roubin 1989; Bigelow 1992; Classen 1992; Van Beek 1992; Ponty 1995; Dulau 1998; Beer 2000; Low 2006, 2009; Candau 2013a.

8. Needham's category-change is used in Howes 1987, while the odour of the dead body is studied in Candau 2013b.

9. Candau 2000, 2007; Howes 2002; Candau \& Jeanjean 2006; Croijmans \& Majid 2016; Majid et al. 2017.

10. See blogger Flaconneur's description of Christopher Brosius and his CB I Hate Perfume Gallery (Flaconneur 2015).

11. Rodaway 1994; Beer 2007.

12. A few examples of the researchers who conduct interdisciplinary linguistic-anthropological research: Holley 1999; Chrea et al. 2009; Candau \& Wathelet 2011; Wnuk \& Majid 2012; Hussain et al. 2013; Beer 2014; Mariani 2015.

13. For example, interdisciplinary scientific and art projects by Sissel Tolaas.

14. The acts of sensation as the interaction between the source and physiological apparatus that treat the stimuli functionally.

15. According to Köster 2002, p. 30, this reference prevails.

16. According to David et al. 1997, this reference expressed by the verbs is more frequent than the reference to sources.

17. See Slezkine 1994; Krupnik \& Chlenov 2013; Yamin-Pasternak et al. 2014; Habeck 2019.

18. It proved to be unfit recently, in particular, in short-lived conjunctions when father of the newborn is anonymised.

19. Meaning e.g. a seasonal builder, an employee of the Housing and communal services (Zhkh: Zhilishchno-kommunalnoe hoziaistvo) hired from the regions outside of the Chukchi peninsula, or even a foreign anthropologist like me.

20. "Our path leads through the poetry of machines, from the bungling citizen to the perfect electric man. [...] The new man, free of unwieldiness and clumsiness, will have the light, precise movements of machines, and he will be the gratifying subject of our films" (Vertov \& Kinoks, 1922 in Michelson 1984, p. 8).

21. Fedor Uyagansky (eth. Even), my informant from Anadyr, email communication 10 June 2018.

22. A sudden withdrawal of people, resources, and services in Siberia and the Far North in the 1990's led to scarcity of all the imported products, including food, medicines, and black coal for heating and electricity, etc. 
23. I.e. it is a subject of numerous informal conversations as well as jokes.

24. Under the governor of Chukotka Autonomous Okrug, Roman A. Abramovich (governing from 2000 until 2008), some hamlets underwent general overhaul; more than $80 \%$ of the houses and service buildings were replaced by the new ones with central heating system, electricity and running water.

25. In the hamlet of New Chaplino, for example, which was established as an amalgam of several Yupik settlements, such as Un'azik, Plover, Kivak, etc., today's residents are aware of their lineage, clan and regional origin (Krupnik \& Chlenov 2013).

26. See also Bagdasarova (Panakova) 2012.

27. See more on this in Bagdasarova (Panakova) 2012.

\section{ABSTRACTS}

The aim of this study is to explore how the smells associated with particular emotions encode the feeling of belonging in Russian Beringia. The differing olfactory patterns are conceptualised within the broad socio-political processes of Soviet and post-Soviet modernisation. The odours, the mental representations of the odorous stimuli, are considered socially constructed. Following David Howes (2002) and Constance Classen et al. (1994), it is assumed that the cultural politics of olfaction intensify under the changing social regimes. The study further draws on David Chaney's concept of lifestyle (1996) that proves to be helpful in enhancing the investigation of the interrelation between social differentiation and aesthetic patterns in the context of the Soviet mission civilisatrice. In the analysis of the impact of the Soviet (and post-Soviet) policies on the native olfactory practices, the study shifts the focus from deodorisation (a concept that refers to elimination of those odours that colonizing western discourse finds socially unacceptable) towards sanitation (process in which cleanliness as a synecdoche for civility may lead to, but not necessarily does, a repudiation of certain odours). It demonstrates that the realms where the senses, aesthetic, and social hierarchies overlap have a wide spectrum of cultural forms, often unintended from the point of view of the Soviet or post-Soviet policy makers.

Cette étude explore comment les odeurs, associées à des émotions particulières, révèlent le sentiment d'appartenance à la Béringie russe. Les différents modèles olfactifs sont conceptualisés dans le cadre de larges processus socio-politiques de la modernisation soviétique et postsoviétique. Les odeurs, les représentations mentales des stimuli odorants, sont considérées socialement construites. Suivant la démarche de David Howes (2002) et de Constance Classen et al. (1994), l'auteur suppose que les politiques culturelles de l'olfaction s'intensifient sous les régimes sociaux changeants. L'étude s'inspire en outre du concept de styles de vie de David Chaney (1996) qui s'avère utile pour approfondir l'étude des relations entre différenciation sociale et modèles esthétiques dans le contexte de la mission civilisatrice soviétique. Dans l'analyse de l'impact des politiques soviétiques (et post-soviétiques) sur les pratiques olfactives indigènes, l'étude déplace l'attention de la désodorisation (un concept qui fait référence à l'élimination des odeurs que le discours occidental colonisateur trouve socialement inacceptables) vers l'assainissement (processus dans lequel la propreté, synecdoque de la civilité, peut entraîner la répudiation de certaines odeurs). Elle démontre que les domaines où les sens, l'esthétique et les hiérarchies sociales se chevauchent, ont un large éventail de formes culturelles, souvent involontaires du point de vue des décideurs politiques soviétiques ou postsoviétiques. 


\section{INDEX}

Keywords: sensory anthropology, olfaction, categorisation, social change, belonging, identity, Chukotka, Russia, Chukchi, Yupik

Mots-clés: anthropologie des sens, olfaction, catégorisation, changement social, appartenance, identité, Tchoukotka, Russie, Tchouktche, Yupik

\section{AUTHOR}

\section{JAROSLAVA PANÁKOVÁ}

Jaroslava Panáková received her PhD in Social Anthropology at St. Petersburg State University in Russia and her MA in documentary cinema at FAMU Prague, Czech Republic. She carried out her postdoctoral research at MPI for Social Anthropology in Halle, Germany and at CNRS, Paris, France. Her research interests include mobility, sensory anthropology, and Siberia. She is currently lecturer at Comenius University in Bratislava, Slovakia, and researcher at the Slovak Academy of Sciences.

Her principal publications are: "Something like happiness. Home photography in the inquiry of lifestyles", in J. O. Habeck (ed.), Lifestyle in Siberia and the Russian North (2019, Cambridge, Open Book Publishers); "Fotografija kak sredstvo prozhivanija skorbi (Providenskij rajon, Čukotka) " [Dealing with grief through photography (Providensky District, Chukotka)] (2018, Kunstkamera 2, pp. 201-208); and "Culture, perception, and artistic visualisation. A comparative study of children'drawings in three Siberian cultural groups" (2014, in co-authorship with K. Istomin \& P. Heady, Cognitive Science 38, pp. 76-100).

haliganda@gmail.com 